\title{
Public Service Quality and Citizen-Client's Satisfaction in Local Municipalities
}

\author{
Jean Claude Mbassi \\ University of Douala \\ Axel Dieudonné Mbarga \\ University of Douala
}

\author{
Richard Nkene Ndeme \\ University of Yaounde II
}

\begin{abstract}
The purpose of this study is to identify, describe and evaluate the link between public service quality and citizen-client's satisfaction in local municipalities. The work is based on the revisited SERVQUAL model. A quantitative research is carried out through a questionnaire administered to 1,427 users of local public services in 21 councils. Two layers of analysis are carried out. First, an exploratory and confirmatory factor analysis. Second an analysis through structural equations. Results show that all aspects of service quality do not contribute identically to users 'satisfaction.
\end{abstract}

Keywords: Public Service Quality, Citizen-client' Satisfaction, Municipality

\section{INTRODUCTION}

According to Hung et al. (2003), providing an excellent level of service quality that will result in a high level of customer satisfaction is of utmost importance and a major challenge for service industries today. Under these conditions, service quality becomes an important issue for both public and private sectors; it is a topical issue at the local level especially in the current context of change and modernization of the society. It is defined as the extent to which a service meets or exceeds the client's needs and expectations (Lewis and Mitchell, 1990; Wisniewski and Donnelly, 1996; Zahari et al., 2008).

Indeed, the modernization of public administrations is now a worldwide necessity (Percebois, 2006). These administrations have undergone many changes over the last few decades, such as the rise of citizens' demands and expectations, and the internalization of the debate on good management practices in the public sector (Hood, 1995, Hood and Dixon, 2013). Implementation of public policies at both the state and the local levels has shifted from the logic of means to that of results. A strong wave of reforms has been initiated to better take into account users' expectations and place them at the heart of the administration's concern. Citizens/users, or customers are increasingly demanding and calling for more transparency, much more efficiency and public service quality. Local public action is then required to 
operate in the most efficient way possible and constantly improve the quality of its services because, particular attention is given to population-citizens or users' jugement on the quality of services offered ( Mayers and Lacey, 1996).

In Cameroon, local authorities play a vital role in local development (Constitutional Law, 1996), stability and improvement of living conditions of the local population (Mokhlis, 2012). They must work to meet the multiple expectations of citizens. However, it is observed that municipalities in Cameroon, as in most developing countries, witness many misfortunes related to rigidity, slowness and heavy bureaucracy (Ben Hanana and Houfaidi, 2014). This is likely to create a discomfort affecting the relationship between the administration and the citizens (Ben Hanana and Houfaidi, 2016). However, for Myers and Lacey (1996), more and more attention must be paid to the judgment of citizen-clients on the quality of local public services offered to them. This quality of service is a pivotal factor in the transformation of municipal services and a critical lever for better citizen's satisfaction.

To really take into account citizen-clients' expectations and better serve them one of the major reforms of the Cameroonian public administration was decentralization. Indeed, since November 2016, people in the North-West and South-West regions of Cameroon have been raising violent complaints (through street demonstrations, ghost cities, burning public buildings, prohibiting students from school, etc.). More than ever, it is the inability for the current form of the state to secure, through local authorities, improvement of the daily living conditions of the population which is pointed out by demonstrators. In this context, characterized by the rise of demands from the population, it becomes imperative for public authorities to put their administration on the path of modernity. Efforts are therefore put in and aim at modernizing public services and creating contest among local public administrations.

In order to enable municipalities to fulfill their mission fully, municipal officials as the main providers of local public services are now interested in evaluating and improving services provided to the people (Titu and Bucur, 2016). It therefore becomes necessary and more important than ever to rethink the local public service, which since the independence of Cameroon in 1960 has undergone some evolution. To achieve this, it will be necessary to promote the concept of quality of services delivered to users, with a view to making public administrations responsive, flexible and constantly adapting to changes in their environment, so as to play the role of socio-economic and cultural development promoter at the local level and therefore better meet populations' expectations (Ben Hanana and Houfaidi, 2016).

Several works suggest that the perception and expectations of the consumer/client are likely to differ among service sectors (Selvakumar, 2015). Service quality is therefore one of the most important criteria in assessing consumer satisfaction (Akinloye Akinboade et al., 2012; Abubakar, 2016; Titu and Bucur, 2016, etc.). On this subject, Mai Ngoc Khuong and Ngo Quang Dai (2016) attempt to show that one of the major challenges for public officials today is how to properly manage or produce quality services for better satisfaction of citizens/consumers. This leads us to the question what influence does local public service quality have on consumer/client satisfaction?

The main objective pursued in this article is to identify, describe and evaluate the relationship between the quality of local public services delivered and citizen-client's satisfaction in local authorities in Cameroon.

An assessment of citizens-clients' satisfaction through quality of services delivered seems to be the only effective way for locally elected representatives to know if services provided by the municipality are in line with the expectations and the needs actually expressed by the population/citizens (Drebin and Brannon, 1990).

The paper includes three sections. The first section focuses on a review of the literature on the main constructs. The second section is concerned with the methodology used. And the last section presents the main results and their implications.

\section{LITERATURE REVIEW}

Service quality evaluation has often been done in two ways: First, measurement and improvement of internal processes in a rational control of industrial operations "the produced quality". Second, 
consideration of users' perceptions of the service enterprise logic "perceived quality" (Goudarzi and Guenoun, 2010). Local authorities have become real service companies, and must provide quality services to the citizens who have also become customers, so as to increase their proximity to the commercial world (Sabadie, 2001). In this article which focuses on assessment of local public services, we rely on the perception of the services' beneficiaries with reference to the pioneer works of Parasuraman et al. (1985, 1988).

\section{Service Quality and Satisfaction with Local Authorities}

For Wisniewski (2001), service quality is a concept that raises considerable interest and debate in the marketing literature because of numerous difficulties, as its definition and measurement leave no room for consensus. However, most service quality definitions imply that its evaluation is based on the measurement, customers/users' perceptions, and adaptation of internal operations to perceptions (Goudarzi and Guenoun, 2010). Perceived service quality is defined by Zeithaml (1981) as "the judgment of the consumer as to the degree of excellence or superiority attributed to an entity". In this definition, service quality is the ability of an organization to meet or exceed consumer expectations (Mokhlis et al., 2011). This definition is part of the process of confirmation/disconfirmation of expectations as developed by Oliver (1980). In this approach, if the actual performance of the service is higher than expected, the consumer will be satisfied with the service and vice versa (Parasuraman and al., 1985). However, other definitions have been based on the formation of perceived service quality. With this approach, supporters of the Nordic school including Grönroos (1984), consider that: "the perceived quality of service is the result of a comparison between the client's expectations and his actual experiences with a service". According to Parasuraman et al. (1988), the perceived quality of service would result from a comparative process between what the client considers to be the service offered by an organization and his perceptions of the organization's performance.

The marketing literature acknowledges that several studies have identified dimensions or determinants of service quality; and consumer satisfaction is often seen as depending on the quality of service (Parasuraman et al., 1985; Grönroos, 1984). There is a variety of analytical models that highlight the most important dimensions of service quality. In this regard, the seminal work of Parasuraman et al. $(1985,1988)$ identified ten dimensions for service quality. These dimensions are at the center of the development of their measurement scale named SERVQUAL. After reviewing their instrument, the authors finally kept five dimensions within which 22 items are grouped, these dimensions include tangible elements, reliability, responsiveness, assurance and empathy. The summary of their work is presented in table 1 below:

TABLE 1

\section{SERVICE QUALITY DIMENSIONS}

\begin{tabular}{l|l}
\hline Dimensions & Content \\
\hline Tangible elements & Physical facilities, equipment and appearance of personnel \\
\hline Reliability & $\begin{array}{l}\text { The perceived ability of the service provider to deliver the promised } \\
\text { service satisfactorily, accurately and consistently }\end{array}$ \\
\hline Responsiveness & $\begin{array}{l}\text { The desire of the organization to efficiently deliver the service, to help } \\
\text { customers and offer a prompt service }\end{array}$ \\
\hline Assurance & level of skill, courtesy and ability to inspire confidence \\
\hline Empathy & Consideration, individualized attention given by the firm to each client \\
\hline
\end{tabular}

Source: Parasuraman et al. (1988). Servqual: A multiple-item scale for measuring consumer perceptions of service quality. Journal of Retailing. 64, 12-40.

For Selvakumar (2015), service quality dimensions developed by Parasuraman et al. (1988) are used to measure the gap between the level of service expected and that which is perceived by customers. The author notes that all five measurement dimensions of service quality substantially influence customer 
satisfaction and even improve elements of service quality which are considered as main antecedents to customer satisfaction. Under such conditions, customer satisfaction appears to strongly require a study and an understanding of consumer behavior today.

Customer satisfaction was first recognized as one of the most important elements of contemporary marketing thinking, particularly in the service sector (Mokhlis et al, 2011), but also as one of the most important marketing objectives (Erevelles and Leavitt, 1992). Since, satisfied customers tend to maintain their mode of consumption or consume more and more of the service. Consumer satisfaction then appears in this case as an important indicator of future behavior (McQuitty et al., 2000). Because of its central role in studies of consumer behavior, various theories and models have been developed in order to define and explain the formation of satisfaction with regard to products and services at different stages of consumption. Satisfaction is then defined by Howard and Sheth (1969) as being appropriately or inadequately rewarded in a buying situation for the efforts made. Oliver (1997) proposes to consider consumer satisfaction as a judgment that occurs, associating cognitive judgment and emotional reaction. So the combination of the cognitive and emotional approaches reveals that satisfaction related to the product or service contains both an emotional and cognitive component and is the result of the comparison between a subjective experience and a baseline.

However, a satisfied consumer will seek to maintain his consumption level; moreover, he will attempt to consume more and more of the same product or service. In the literature, there is no agreement among researchers on antecedents of service quality and satisfaction (Ting, 2004). Nonetheless, the consumer's judgment on the service shows that, in a temporal perspective, the judgment of perceived quality is an antecedent of satisfaction (Teas, 1993; Parasuraman et al., 1994b; Rust and Olivier, 1994; Llosa, 1996; Ngobo 1997; Dabholkar et al., 2000). This work, which fits into this logic, will therefore lead us to demonstrating the existence of a theoretical link between service quality and satisfaction, especially with regard to the provision of local public service.

\section{Service Quality and Satisfaction: A Relationship in Quest for A Meaning in The Field of Local Authorities}

In order to measure service quality, several other works have been developed. In this regard, the Canadian initiative in the public sector with "Citizens First" draws a picture of the perception of Canadian citizens with respect to their public services so as to suggest areas of improvement. As well as the SERVQUAL, "the Quebec measurement tool (OQM)" aims to evaluate the quality of services and the satisfaction of users (Trembley, 2006). Like SERVQUAL, this tool is also universal, based on a series of statements that revolve around three main variables: quality, results and costs. From all these works, despite critics including those from Cronin and Taylor (1994), SERVQUAL seems more elaborate. Indeed, SERVQUAL has been subject to several replications in both private and public sectors. Within the municipal public sector, SERVQUAL offers the possibility of adding other dimensions, especially those specific to local public services (Sabadie, 2003). These specificities can then refer to, among other things, the fair treatment of users which provides them with the right to reeive the same treatment in the face of a service; participation as an important element in the municipal context where citizens are now co-producers of local public policies (Lamarche, 2001); transparency in the sense that the basic moral claim in democratic societies is the right for the population to have access to information from the local authorities (Pasquier and Villeneuve, 2007). These elements specific to the local context therefore seem to be the basis of citizen-client satisfaction.

Akinloye Akinboade et al. (2012), in their analysis of citizen satisfaction with public services in the Sedibeng Municipal District of South Africa, state that there is a very significant link between dimensions of service quality and citizens' satisfaction. Specifically, these authors show that consumers are poorly satisfied with the quality of basic services, particularly infrastructures such as: roads, job creation or the reduction of crime rate. For researchers, these elements will represent real challenges in the future for the South African government. On the other hand, citizens and/or users seem quite satisfied with the supply of water and electricity. In the same vein, Mai Ngoc Khuong and Ngo Quang Dai (2016), as part of their study on explanatory factors of users' satisfaction and loyalty with public transport service, show that 
only two related variables (comfort and price) appear significant with satisfaction at the threshold of $1 \%$. As a result, these variables account for $28.6 \%$ of variation in user's satisfaction. Titu and Bucur (2016) on their own will develop a synthetic service quality index for management of local public administrations. For these authors, this global index can be mobilized by researchers from different disciplines to assess the achievement of municipal objectives, which include the quality of public service and improvement in efficiency.

Works in the context of public services in general and local public services in particular, consider the five dimensions of PZB model (Mokhlis, 2011, 2012; Wisniewski, 2001; Donnelly et al., 1995; Nielsen and Host, 2000; Rodriguez et al., 2009). In this perspective, Goudarzi and Guenoun (2010) have considered the specific dimensions of public service identified by Sabadie in their work (2003). However, the accessibility dimension has often subsidiarily appeared in some works and is summarized by the layout of the premises and opening and closing hours of the service, thus obscuring the different users' social and geographical conditions in order to restore equal access to the service (Goudarzi and Guenoun, 2010). Yet, the present work is conducted in the field of local communities characterized by a high rate of impoverishment for local populations. Here, services delivered by the municipalities have an important physical support (drinking water, road infrastructure, health care which requires prior existence of equipped health centers and nurses, school halls, teachers, etc.). In addition, the type of contact between citizens and the most common municipality is indirect (Brown, 2007), since the number of citizens who use roads, public lighting, recreation centers, etc. is more important than the number of citizens who go to the municipal council to certify a document, get a birth certificate or request any other service. An assessment of services in this context is therefore highly dependent on the existence of basic services and social goods, but much more on their functioning.

From the perspective of functional accessibility to local public services, Kimenyi and Shugart II (2012) argue that in Africa, many services are physically accessible, but not functional. Functional accessibility is particularly important especially for the poor who cannot use alternative means of accessing services. This facet of service quality seems important to us in the context of Cameroonian municipalities in that many basic services and social goods that contribute to the improvement of living conditions of the populations don't exist. Even when they exist, they are most often non-functional. From the literature mobilized on local public services quality, we can note that accessibility has never really been the focus of researchers' attention. Moreover, no service charter like the Marianne Charter in France is visibly defined in the Cameroon context. It is this situation that inspired the present work which tries to fill this gap so as to shed more light on the relationship between the local public service quality and users/customers' satisfaction. To do so, we adopted a suitable methodological approach.

\section{METHODOLOGY}

In order to study the relationship between public service quality and users' satisfaction in the field of Cameroonian municipalities, we used SERVQUAL as an evaluation tool set up by Parasuraman et al. (1988). The different quality of service items from SERVQUAL are measured with a 5-point Likert scale ranging from "1 Strongly disagree" to "5 Strongly agree" to meet up with homogeneity constraints posed by a large number of statistical treatments. The score for each dimension is an average of the sum corresponding to the score of each item. Again, in order to capture information that relates to the satisfaction of citizens-clients with local public services, the same five-point scale was favored and adapted with reference to the work of Sabadie (2001).

Data for this research came from a survey conducted between May and July 2016 by ESSEC (Higher School of Economics and Business) students from the University of Douala on 1,427 residents from 21 municipalities in Cameroon. The municipalities in the sample are located in the Center (5 municipalities) and Littoral (4 municipalities) regions, Yaoundé (7 municipalities) and finally Douala (5 municipalities).

As far as data analysis is concerned, we first of all used exploratory factor analysis to reduce the number of dimensions and foster emergence of a model for the analysis. In a second step, confirmatory 
factor analysis confirmed the model derived from exploratory factor analysis. Finally, structural equations measured the intensity of the relationship between perceived quality and citizen-client satisfaction.

\section{RESULTS AND DISCUSSION}

\section{Demographic Characteristics}

Table 2 presents frequencies distribution of the respondents' profile. The sample consists of 1,427 households from 21 municipalities. We thus have, 56\% of men against $44 \%$ of women, with a predominance of the age group [18-35] years, that is to say $46 \%$ of the respondents. Considering the level of education, $56 \%$ of those surveyed have a high school level and $29 \%$ a higher school level. The majority of respondents report an income below 36,470 FCFA (32\%) representing the SMIC (Minimum Interprofessional Guaranteed Salary) in Cameroon. Trade is mostly represented among occupations of citizenclients in sampled municipalities.

TABLE 2

\section{RESPONDENTS CHARACTERISTICS}

\begin{tabular}{|c|c|c|c|}
\hline Variables & Items & Frequencies & Percentages (\%) \\
\hline \multirow{3}{*}{ Gender } & Men & 804 & 56.34 \\
\hline & Women & 623 & 43.66 \\
\hline & Total & 1,427 & 100.00 \\
\hline \multirow{4}{*}{ Age } & $18 \sim 35$ years & 657 & 46.04 \\
\hline & $36 \sim 55$ years & 634 & 44.43 \\
\hline & 56 years and above & 136 & 09.53 \\
\hline & Total & 1,427 & 100.00 \\
\hline \multirow{5}{*}{ Education level } & No level & 62 & 04.34 \\
\hline & Primary & 162 & 11.35 \\
\hline & Secondary & 794 & 55.64 \\
\hline & higher & 409 & 28.66 \\
\hline & Total & 1,427 & 100.00 \\
\hline \multirow{11}{*}{ Profession } & Traders & 237 & 16.61 \\
\hline & Students & 166 & 11.63 \\
\hline & Teachers & 144 & 10.09 \\
\hline & Technicians & 109 & 07.64 \\
\hline & Liberal Profession & 96 & 06.73 \\
\hline & Housewives & 83 & 05.82 \\
\hline & Unemployed & 74 & 05.19 \\
\hline & Clerk & 68 & 04.77 \\
\hline & Retired & 55 & 03.85 \\
\hline & Others & 395 & 27.68 \\
\hline & Total & 1,427 & 100.00 \\
\hline \multirow{8}{*}{ Income } & Below 36,470 FCFA & 460 & 32.24 \\
\hline & $36,470 \sim 72,940$ FCFA & 286 & 20.04 \\
\hline & $72,940 \sim 145,880 \mathrm{FCFA}$ & 343 & 24.04 \\
\hline & $145,880 \sim 291,760 \mathrm{FCFA}$ & 250 & 17.52 \\
\hline & $291,760 \sim 583,520 \mathrm{FCFA}$ & 74 & 05.10 \\
\hline & $583,520 \sim 1,167,040$ FCFA & 10 & 00.70 \\
\hline & Above $1,167,040$ FCFA & 04 & 00.28 \\
\hline & Total & 1,427 & 100.00 \\
\hline
\end{tabular}

Source : Study's Results 


\section{Assessing the Quality of Measurement Instruments}

Exploratory Factor Analysis

The exploratory factor analysis (Table 3) of perceived quality as well as tests that relate to validity and reliability of the measurement instruments are carried out using SPSS 20 software. Items whose correlation coefficients are less than 0.5 have been removed in order to improve the readability of the results. Since, according to Lim (1996), an item is significant when its contribution factor is greater than 0.5 . The principal components analysis shows 8 factors whose eigenvalues are greater than 1 , contributing to $67.31 \%$ of the total variance. Factors selected are: F1 = Participation (9 items), F2 = Empathy ( 9 items), F3 = Assurance ( 8 items), F4 = Transparency ( 9 items), F5 = Accessibility (5 items), F6 = Tangibility (5 items), F7 = Equal treatment (3 items) and finally F8 = Reliability (3 items). Bartlett's sphericity test is significant $(\mathrm{p}<0.000)$ and $\mathrm{KMO}$ index stands at 0.97 . Coefficients of internal coherence (Cronbach Alpha) are very satisfactory and found in between 0.77 and 0.93 .

TABLE 3

EXPLORATORY FACTOR ANALYSIS FOR PERCEIVED QUALITY

\begin{tabular}{|c|c|c|c|c|c|c|c|c|c|}
\hline \multirow{2}{*}{ Items } & \multicolumn{9}{|c|}{ Factor } \\
\hline & F1 & F2 & F3 & F4 & F5 & F6 & F7 & F8 & Com \\
\hline PARTICIP4 & 724 & 135 & 153 & 238 & 155 & 049 &,- 005 & 143 & 705 \\
\hline PARTICIP3 & 721 & 271 & 223 & 227 & 115 & , 132 &,- 024 & 090 & 649 \\
\hline PARTICIP7 & 705 & 167 & 150 & 302 & 150 & 139 &,- 006 & 102 & 724 \\
\hline PARTICIP5 & 705 & 278 & 195 & .227 & 218 & 143 & 039 &,- 006 & 688 \\
\hline PARTICIP6 & 694 & 273 & .188 & 227 & 176 & 127 & .068 & -036 & 688 \\
\hline PARTICIP8 & 625 & 073 & 167 & 264 & 102 & .198 & 024 & 199 & 605 \\
\hline PARTICIP1 & 625 & 102 & 016 & 141 & 006 & 093 & 037 & 309 & 563 \\
\hline PARTICIP9 & 587 & 269 & 130 & 186 & 276 & 244 & 086 & 058 & 621 \\
\hline PARTICIP2 & 582 & 372 & 187 & 165 & 231 & 218 & 063 & .016 & 552 \\
\hline EMPA1 & 230 & 664 & 240 & 148 & 159 & 139 &,- 112 & 067 & 583 \\
\hline EMPA2 & 244 & 650 & 280 & 219 & 172 & 118 &,- 044 & 069 & 668 \\
\hline EMPA8 & 169 & 650 & 268 & 197 & 112 & 135 & .001 & 218 & 741 \\
\hline EMPA7 & 214 & 643 & 168 & 195 & 077 & 049 &,- 039 & 262 & 708 \\
\hline EMPA3 & 222 & 622 & 341 & 186 & 252 & 165 & 097 & 063 & 721 \\
\hline EMPA5 & 261 & 589 & 304 & 229 & 260 & .134 & 058 & .085 & 722 \\
\hline EMPA4 & 303 & 585 & 324 & 194 & 265 & 137 & 050 & 068 & 595 \\
\hline EMPA6 & 196 & 532 & 250 & .185 & 107 & 020 &,- 145 & 289 & 615 \\
\hline EMPA10 & 143 & 509 & 370 & 254 & 199 & 175 &,- 023 & 104 & 620 \\
\hline ASSU5 & 155 & 204 & .715 & 181 & 175 & 247 &,- 112 & 112 & 666 \\
\hline ASSU6 & 146 & 182 & 711 & 175 & 184 & 143 &,- 033 & 123 & 660 \\
\hline ASSU4 & 160 & 240 & 694 & 164 & 077 & 189 &,- 085 & 164 & 725 \\
\hline ASSU2 & 137 & 362 & 689 & 133 & 174 & 238 &,- 004 &,- 012 & 726 \\
\hline ASSU8 & 119 & 189 & 680 & 174 & 176 & .081 & 093 & 183 & 741 \\
\hline ASSU3 & 108 & 385 & 679 & 132 & 159 & 266 & 050 &,- 004 & 684 \\
\hline ASSU1 & 151 & 387 & 658 & 126 & 177 & 225 & 008 &,- 026 & 648 \\
\hline ASSU7 & 241 & 120 & 610 & 087 & 111 & 032 & 024 & 220 & 703 \\
\hline TRANSP3 & 321 & 190 & 153 & 709 & 092 & 133 &,- 081 & 178 & 540 \\
\hline TRANSP4 & 233 & 207 & 211 & 696 & 187 & 168 &,- 018 & 167 & 729 \\
\hline TRANSP7 & 298 & 137 & 176 & 685 & 186 & 139 &,- 020 & 162 & 677 \\
\hline TRANSP6 & 317 & 190 & 164 & 668 & 191 & 131 & 078 & .094 & 718 \\
\hline |TRANSP9 & 230 & 108 & 148 & 651 & 205 & ,096 & $F, 115$ & 264 & 671 \\
\hline
\end{tabular}




\begin{tabular}{|c|c|c|c|c|c|c|c|c|c|}
\hline \multirow[b]{2}{*}{ Items } & \multicolumn{9}{|c|}{ Factor } \\
\hline & F1 & F2 & F3 & F4 & F5 & F6 & F7 & F8 & Com \\
\hline TRANSP5 & 249 & 393 & 184 & 591 & 226 & 132 & 078 & 025 & 632 \\
\hline TRANSP8 & 185 & 324 & 161 & 580 & 330 & 134 & 119 &,- 005 & .732 \\
\hline TRANSP1 & 344 & 330 & 138 & 534 & 153 & 188 & 085 & 085 & 652 \\
\hline TRANSP2 & 248 & 452 & 164 & 508 & 245 & 164 & 083 &,- 045 & 560 \\
\hline ACCESS3 & 210 & 178 & 196 & 176 & 719 & 175 & 028 & 032 & 580 \\
\hline ACCESS4 & 215 & 220 & 255 & 290 & 691 & 139 & 006 & 117 & 862 \\
\hline ACCESS2 & 287 & 248 & 231 & 271 & 674 & 145 &,- 107 & 077 & 825 \\
\hline ACCESS5 & 168 & 247 & 261 & 300 & 672 & 157 &,- 002 & 101 & .732 \\
\hline ACCESS1 & 238 & 291 & 244 & 299 & 653 & 157 &,- 075 & 088 & 831 \\
\hline TANG3 & 212 & 212 & 224 & 165 & 132 &, 735 & 017 & 035 & 826 \\
\hline TANG2 & 213 & 228 & 209 & 163 & 173 &, 721 & 023 & 096 & 675 \\
\hline TANG1 & 195 & 165 & 210 & 088 & 237 &, 701 & 094 & 051 & 630 \\
\hline TANG4 & 202 & 100 & 220 & 190 & 037 &, 698 &,- 005 & 222 & 649 \\
\hline TANG5 & 069 &,- 052 & 243 & 232 & 115 &, 537 &,- 091 & 392 & 705 \\
\hline EQU_TRAET5 & 037 &,- 050 &,- 027 & 005 &,- 005 & 031 & 913 & 079 & 649 \\
\hline EQU_TRAET6 & 018 &,- 055 &,- 035 & 015 & -015 & 049 & 892 & 068 & 724 \\
\hline EQU_TRAET4 & 063 & 041 & 026 & 005 & -016 &,- 029 & 840 &,- 020 & 688 \\
\hline RELIABA11 & 121 & 209 & 125 & 089 & 054 & 112 & 151 & 778 & 688 \\
\hline RELIAB12 & 184 & 241 & 097 & 141 & 120 & 100 & 020 & 726 & 605 \\
\hline RELIAB10 & 147 & 061 & 253 & 226 & 027 & 195 & 020 & 600 & 563 \\
\hline Variance explained (\%) & 41.83 & 5.67 & 4.85 & 3.95 & 3.33 & 3.18 & 2.31 & 2.19 & 67.31 \\
\hline Cronbach Alpha & 0.92 & 0.92 & 0.92 & 0.93 & 0.91 & 0.86 & 0.88 & 0.77 & \\
\hline Bartlett's Test Sign & & & & & 0.000 & & & & \\
\hline KMO index & & & & & 0.970 & & & & \\
\hline
\end{tabular}

Source: Study's results.

\section{Confirmatory Factor Analysis}

The confirmatory factor analysis is carried out with AMOS 20 software, based on the dimensions from exploratory factor analysis. It provides the adjustment indices and indicator values needed to estimate internal consistency and construct validity of the measurement scale. We note that the fit of the model is correct considering indices retained $(\chi 2=2073.980, \chi 2 / \mathrm{dl}=4.441$, CFI $=0.952$, GFI $=0.923$, AGFI $=0.940$, RMR $=0.072$, RMSEA $=0.049$, AIC of the model $=2327.980<33952.510$ of the independent model).

With regard to the internal consistency of the measurement tool, the Jôreskog's $\rho$ are respectively 0.86 for the Tangibility dimension, 0.90 for the Assurance dimension, 0.77 for the Empathy dimension, and 0.76 for the reliability dimension, 0.71 for the Transparency dimension, 0.80 for the Equal Treatment dimension, 0.92 for the Participation dimension, 0.88 for the Accessibility dimension. They are all above the 0.7 threshold.

Fornell and Larcker (1981) argue that a scale of measurement meets the criterion of convergent and discriminant validity when each construct shares more than $50 \%$ of variance with its measures. Therefore, Table 0.4 shows how each construct shares more variance with its measures than with the other constructs. 


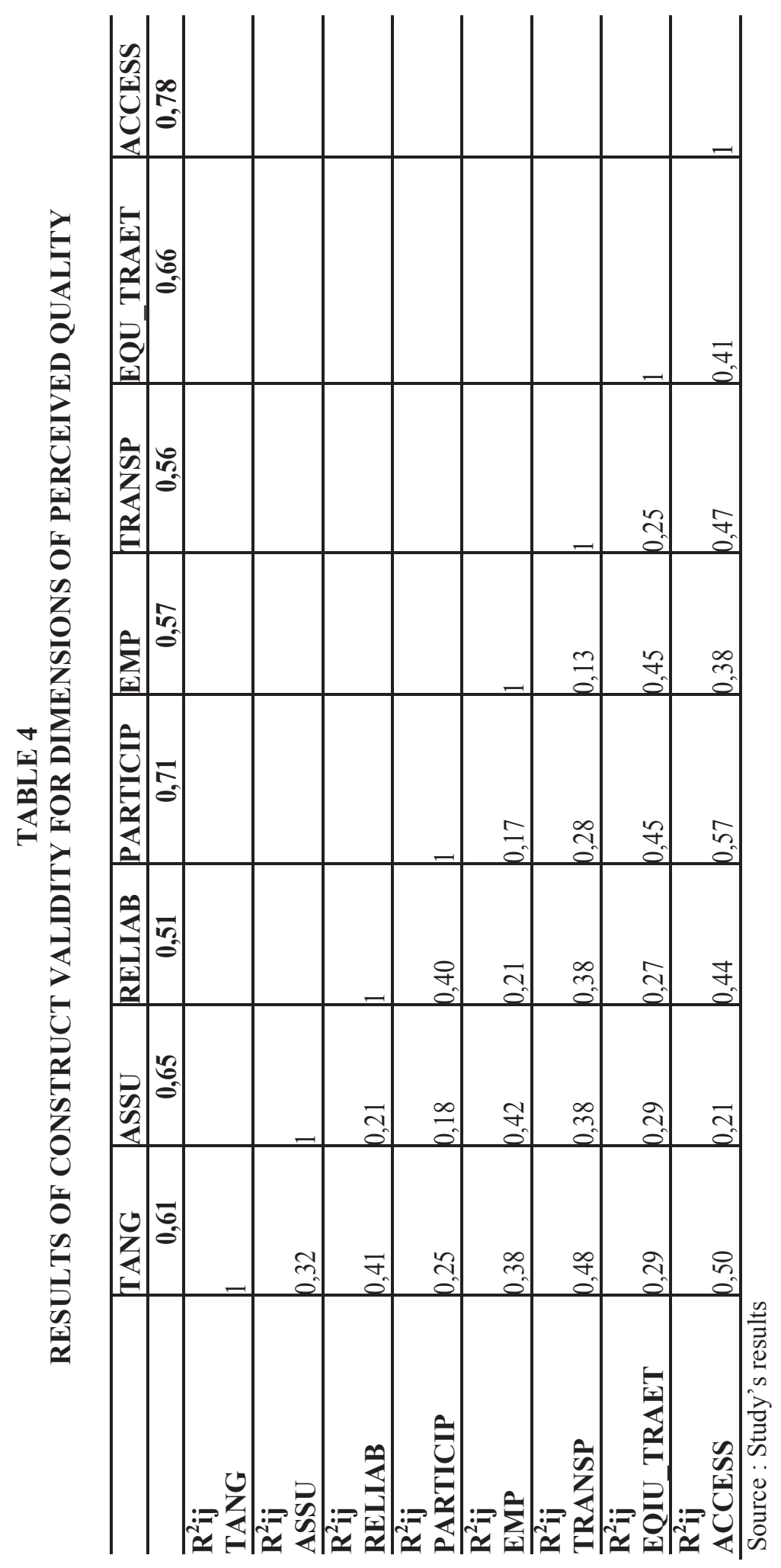




\section{The Structural Equation Model}

We used structural equation modeling method to estimate the relationship between quality perceived by citizen-customers and their satisfaction. Structural equation models are used to check whether regressions highlighted between the latent variables correspond to significant causal links while taking into account measurement errors (Ben Hanana and Houfaidi, 2016). Therefore, to study the fit of the model with the data, indices used in the confirmatory factor analysis are also considered. To establish the influence relationship between service quality and users' satisfaction, a structural model is built up with AMOS 20. Moreover, we try to mobilize this technique because it was used by Rahman et al. (2016) as part of their study on the perception of service quality in urban transport operations in a developing country. To ensure correct fit of theoretical variables to the data collected on the Cameroonian municipal field, we used indices in Table 5

TABLE 5

STRUCTURAL MODEL RESULTS FOR QUALITY AND SATISFACTION

\begin{tabular}{|c|c|c|}
\hline Relationship tested & $\begin{array}{l}\text { Structural } \\
\text { coefficients }\end{array}$ & Threshold \\
\hline Tangibility / Quality $: \lambda_{1.1}$ & 0.821 & 0.00 \\
\hline Assurance / Quality $: \lambda_{1.2}$ & 0.966 & 0.00 \\
\hline Reliability / Quality: $\lambda_{1.3}$ & 0.609 & 0.00 \\
\hline Empathy / Quality $: \lambda_{1.4}$ & 0.935 & 0.00 \\
\hline Accessibility / Quality $: \lambda_{1.5}$ & 0.991 & 0.00 \\
\hline Transparency/ Quality: $\lambda_{1.6}$ & 0.889 & 0.00 \\
\hline Participation / Quality $: \lambda_{1.7}$ & 0.906 & 0.00 \\
\hline Equality of treatment / Quality $: \lambda_{1.8}$ & 0.018 & 0.65 \\
\hline Perceived quality / Satisfaction : $\gamma_{1}$ & 0.89 & $\mathbf{0 . 0 0}$ \\
\hline$\chi^{2}$ & \multicolumn{2}{|c|}{$786.454(\mathrm{p}<0.01)$} \\
\hline$\chi^{2} / \mathrm{df}$ & \multicolumn{2}{|c|}{1.991} \\
\hline RMR & \multicolumn{2}{|l|}{0.076} \\
\hline RMSEA & \multicolumn{2}{|l|}{0.026} \\
\hline CFI & \multicolumn{2}{|l|}{0.941} \\
\hline GFI & \multicolumn{2}{|l|}{0.931} \\
\hline AGFI & \multicolumn{2}{|l|}{0.908} \\
\hline $\begin{array}{l}\text { AIC of the model / AIC of the independent } \\
\text { model }\end{array}$ & \multicolumn{2}{|c|}{$1052.367<7234.118$} \\
\hline
\end{tabular}

Source: Study's results

It is clear from the table above that perceived quality of local public services has a significant influence on citizen-client's satisfaction. However, not all dimensions of this concept of quality contribute in the same way to satisfaction of the main users of municipal services. For this reason, Accessibility, Assurance, Empathy and Participation dimensions would better explain satisfaction in the Cameroonian municipal context given their high structural coefficients.

The relative importance and weight of each dimension must be meticulously and appropriately addressed by municipal councils. Citizen satisfaction is a multidimensional construct (Trembley, 2006); it becomes necessary in the process of improving it to take into account the specificities of each attribute or dimension. In a context marked by a desire to enable local populations make decisions about their daily lives combined with a strong impoverishment, efforts of local governments to understand the needs and expectations of the population are the foundation for improvement of their living conditions. At the same time, this participation does not seem to have been achieved since the promulgation of laws on 
decentralization. However, in a representative democracy, the point of view of the local populations or their representatives in elaboration and execution of public policies is essential. Thus, they or at least their representatives as "watchdogs" will act by ensuring that the goods and services delivered are of quality (World Bank, 2000, 2001).

Further, given the embryonic nature of social structures in these municipalities, accessibility of basic social services deserve special attention. Given the limited capacity of municipalities, local governments need to further improve the functional accessibility of basic infrastructure which is more important for the poor (Kimenyi and Shugart, 2012). For services that require physical presence of the service provider (municipal agent) and the consumer (citizen-client), user's trust through reception, listening and guidance are aspects that should be capitalized by the front office of the municipality in the interest of users and their satisfaction. The citizen-client must as well throughout his quest for the service receive special attention not only from municipal officials but also from locally elected officials who are precursors of local public policies. Finally, the provision of a substantial flow of information is a necessity (Holzner and Holzner, 2006; Piotrowski, 2007). Transparency according to Hood (2006) has become a very important issue in all or almost all organizations whether public or private, large or small. Thus, local populations have the right to access information relating to the management of their municipalities, this information being an important element in a representative democracy (Pasquier and Villeneuve, 2007).

\section{CONCLUSION}

The evolution of the municipal context in Cameroon highlights at a point, with no doubt, the will of rulers to provide solutions to demands and expectations of the local population. The 1996 constitution is a response to the concerns of the local people for improvement of their living conditions. Thus, services delivered by the local communities influence the daily life of users. Because of this their capacity to meet user' expectations is an absolute necessity for locally elected representatives and a source of value for the local population. However, the services offered by municipalities to users are composed of several dimensions or attributes that are evaluated by local populations. These attributes contribute in a different way to the satisfaction of the citizen-customer. Thus, the municipal councils must, identify these dimensions and act on those that contribute the most to satisfaction and which are valued by the local population. Highlighting these dimensions gives levers on which mainly locally elected officials must act to improve not only satisfaction which is an important element in municipal management but also ascertain their position at the head of the local communities. 


\section{REFERENCES}

Abubakar, I. R. (2016). Quality dimensions of public water services in Abuja, Nigeria. Utilities Policy, $38,43-51$.

Akinloye Akinboade, O., Kinfack, E. C., \& Mokwena, M. P. (2012). An analysis of citizen satisfaction with public service delivery in the Sedibeng district municipality of South Africa. International Journal of Social Economics, 39(3), 182-199.

Ben Hanana, E., \& Houfaidi, S. (2014). Application du modèle qualité (CAF) dans les administrations publiques : cas du Maroc. Sciences Lib Editions Mersenne, 6, $\mathrm{N}^{\circ} 141114$.

Ben Hanana, E., \& Houfaidi, S. (2016). Proposition d'un instrument de mesure de la qualité de service perçue par les usagers des administrations publiques Marocaines. European Scientific Journal, 12(29), 289-306.

Brown, T. (2007). Coercion versus Choice: Citizen Evaluations of Public Service Quality across Methods of Consumption. Public Administration Review, 67(3), 559-572.

Brown, S., \& Coulter, P. B. (1983). Subjective and objective measures of police service delivery. Public Administration Review, 43(2), 50-59.

Cronbach, L. J. (1951). Coefficient Alpha and the Internal Structure of Test. Psykometrika, 16(7), 297334.

Cronin, J. J., \& Taylor, S. A. (1994). SERVPERF versus SERVQUAL: Reconciling Performance-based and Perceptions-Minus-Expectations measurement of service quality. Journal of Marketing, $58(1), 125-131$.

Dabholkar, P. A., Shepherd, C. D., \& Thorpe, D. I. (2000). A comprehensive framework for service quality. Journal of Retailing, 76(2), 169-173.

Drebin, A., \& Brannon, M. (1990). Police department programs, In H. P. Hatry, J. R. Fountain. Jr., J. M. Sullivan, and L. Kremer (Eds). Service efforts and accomplishments reporting: Its time has comean overview (GR07, 308). Norvalk, CT: Government Accounting Standards Board.

Erevelles, S., \& Leavitt, C. (1992). A comparison of current models of consumer satisfaction/dissatisfaction. Journal of Consumer Satisfaction Dissatisfaction and Complaining Behavior, 5, 104-114

Fornell, C., \& Larcker, D. F. (1981). Evaluating Structural Equation Models with Unobservable Variables and Measurement Error. Journal of Marketing Research, 18(2), 39-50.

Goudarzi, K., \& Guenoun, M. (2010). Conceptualisation et Mesure de la qualité des services publics dans une collectivité territoriale. Politique et Management Public, 27(3), 31-54.

Grönroos, C. (1984). A Service quality model and its marketing implications. European Journal of Marketing, 18(4), 37-44.

Holzner, B., \& Holzner, L. (2006). Transparency in global change-The vanguard of the open society. Pittsburgh, PA: University of Pittsburgh Press.

Hood, C. (1995). The new public management in the 1980s: variations on a theme. Accounting Organisations and Society, 20, 93-109.

Hood, C. (2006). Transparency in historical perspective. In C. Hood and D. Heald. Transparency-The key to better governance. New York: Oxford University Press.

Hood, C., \& Dixon, R. (2013). A Model of Cost-Cutting in Government? The Great Management Revolution in UK Central Government Reconsidered. Public Administration, 91(1), 114-134. doi:10.1111/j.1467-9299.2012.02072.x.

Howard, J., \& Sheth, J. (1969). The theory of buyer behavior. New York John Wiley and sons.

Hung, Y.H., Huang, M.L. \& Chen, K.S. (2003). Service quality evaluation by service quality performance matrix. Total quality Management \& Business Excellence, 14(1), 79-89.

Jöreskog, K. G. (1971). Statistical Analysis of Sets of Congeneric Tests. Psykometrika, 36(6), 109-133.

Kimenyi, M., \& Shugart II, W. (2012). Provider Competition, Marketization and the Quality of Public Service Provision. Institution and Service Delivery. AERC, 267-303. 
Kuaté, J-P. (2012). Les collectivités territoriales décentralisées au Cameroun. Recueil des textes. Cinquième édition.

Lamarche, T. (2001). Service public: nouvelle rationalité des acteurs ou nouveau marché? Etudes de communications, 23, 69-88.

Lewis, B. R., \& Mitchell, V.W. (1990). Defining and measuring the quality of customer service. Marketing Intelligence and Planning, 8(6), 11-17.

Lim, J. W. (1996). Relationship Marketing and Relationship Merit. Korean Marketing Research, 7(1), 173-195.

Llosa, S. (1996). Contribution à l'étude de la satisfaction dans les services. Thèse pour le Doctorat nouveau régime ès-sciences de gestion. Université de Droit, d'Economie et des Sciences d'AixMarseille, Institut d'Administration des Entreprises.

Mai Ngoc Khuong Ngo Quang Dai (2016). The factors affecting customer satisfaction and customer loyalty - a study of local taxi companies in Ho Chi Minh city, Vietnam. International Journal of Innovation, Management and Technology, 7(5), 228-233.

Mayers, R., \& Lacey, R. (1996). Satisfaction du consommateur, performance et responsabilité au sein du secteur public. Revue Internationale des Sciences Administratives, 3, 395-419.

McQuitty, S., Finn, A., \& Wiley, J. B. (2000). Systematically varying consumer satisfaction and its implications for product choice. Academy of Marketing Science Review.

Mokhlis, S. (2012). The Influence of Service Quality on Satisfaction: A Gender Comparison. Public Administration Research, 1(1), 103-112.

Mokhlis, S., Aleesa, Y., \& Mamat, I. (2011). Municipal service quality and citizen satisfaction in southern Thailand. Journal of Public Administration and Governance, 1(1), 122-137.

Ngobo, P. V. (1997). Qualité perçue et satisfaction des consommateurs : un état des recherches. Revue Française du Marketing, 163(3), 67-79.

Nielsen, J. F., \& Host, V. (2000). The path to service encounter performance in public and private bureaucracies. The Service Industries Journal, 20(1), 40-60.

Oliver, R. L. (1997). Satisfaction: Behavioral Perspective on the Consumer. McGraw-Hill International Editions.

Parasuraman, A., Zeithaml, V. A., \& Berry, L. L. (1985). A conceptual model of service quality and its implications for future research. Journal of Marketing, 49, 41-50.

Parasuraman, A., Zeithaml, V. A., \& Berry, L. L. (1988). Servqual: A multiple-item scale for measuring consumer perceptions of service quality. Journal of Retailing, 64, 12-40.

Parasuraman, A., Zeithaml, V. A., \& Berry, L. L. (1994a). Alternative scales for measuring service quality: a comparative assessment based on psychometric and diagnostic criteria. Journal of Retailing, 70(3), 201-30.

Parasuraman, A., Zeithaml, V., A., \& Berry, L. L. (1994b). Reassessment of expectations as a comparison standard in measuring service quality: implications for further research. Journal of Marketing, 58 (January), 111-24.

Pasquier, M., \& Villeneuve, J-P. (2007). Les entraves à la transparence documentaire. Établissement d'une typologie et analyse des comportements organisationnels conduisant à empêcher ou à restreindre l'accès à l'information. Revue Internationale des Sciences Administratives, 73(1), 163-180.

Percebois, L. (2006). La promotion de la performance de l'administration publique dans un contexte d'État interventionniste : le paradoxe scandinave. Colloque International Etat et Régulation Sociale: Comment penser la cohérence de l'intervention publique? 11, 12 \& 13 September, 1-19.

Piotrowski, S. J. (2007). Governmental transparency in the path of administrative reform. Albany, NY: State University of New York Press.

Rahman, F., Das T., Md Hadiuzzaman, \& Hossain, S. (2016). Perceived service quality of paratransit in developing countries: A structural equation approach. Transportation Research, Part A(9)3, 2338 .

122 Journal of Marketing Development and Competitiveness Vol. 13(3) 2019 
Rodriguez, P. G., Burguete, V., Vaughan, R., \& Edwards, J. (2009). Quality dimensions in the public sector: municipal services and citizen's perception. International Revue of Public and Nonprofit Marketing, 6, 75-90.

Rust, R. T., \& Oliver, R. L. (1994). Service quality: insights and managerial implications from frontier. Service quality: new directions. In: Theory and practice. Sage Publications, Thousand Oak.

Sabadie, W. (2001). Contribution à la mesure de la qualité perçue d'un service public. Thèse de Sciences de Gestion, Université des Sciences Sociales de Toulouse.

Sabadie, W. (2003). Conceptualisation et mesure de la qualité perçue d'un service public. Recherche et Applications en Marketing, 18(1), 1-18.

Selvakumar, J. J. (2015). Impact of service quality on customer satisfaction in public sector and private sector banks. VARANASI, 8(1), 1-12.

Teas, K. R. (1993). Expectations, performance evaluation and consumers' perceptions of quality. Journal of Marketing, 25(5), 18-34.

Ting, D. H. (2004). Service quality and satisfaction perceptions: Curvilinear and interaction effect. International Journal of Bank Marketing, 22(6), 407-420.

Titu, M. A., \& Bucur, A. (2016). Models for quality analysis of services in the local public administration. Qual Quant, 50, 921-936, DOI 10.1007/s11135-015-0183-3.

Tremblay, P. (2006). Mesurer la satisfaction et les attentes des clients : des modèles classiques aux modèles asymétriques. Centre d'expertise des grands organismes.

Wisniewski, M. (2001). Using SERVQUAL to assess customer satisfaction with public sector services. Managing Service Quality, 11(6), 380-388.

Wisniewski, M., \& Donnelly, M. (1996). Measuring service quality in the public sector: the potential for SERVQUAL. Total Quality Management, 7(4), 357-365.

Zahari, W., Yusoff, W., \& Ismail, M. (2008). FM-SERVQUAL: a new approach of service quality measurement framework in local authorities. Journal of Corporate Real Estate, 10(2), 130-144.

Zeithaml, V. (1981). How consumer evaluation processes differ between goods and services. AMA Proceedings, 186-190. 